\author{
O. Tomasz Gałkowski CP \\ WPK UKSW \\ ORCID 0000-0001-9166-9516
}

Ius Matrimoniale

30 (2019) nr 2

DOI:10.21697/im.2019.30.2.03

\title{
Zgoda małżonków w procesie skróconym przed biskupem
}

Treść: Wstęp. 1. Odpowiedź na wątpliwość. 2. Racje uzasadniające. 3. Ranga odpowiedzi Papieskiej Rady ds. Tekstów Prawnych. 4. Inne możliwości spojrzenia na kwestię uzyskania zgody. Zakończenie.

\section{Wstęp}

Podjęcie zagadnienia obopólnej zgody małżonków na prowadzenie sprawy o stwierdzenie nieważności małżeństwa w procesie skróconym przed biskupem może wydawać się zbyteczne. Kwestia dotycząca sposobu uzyskania zgody drugiego małżonka, gdy zgłoszenie zostało złożone tylko przez jednego z nich ${ }^{1}$, doczekała się rozwiązania w postaci odpowiedzi Papieskiej Rady ds. Tekstów Prawnych ${ }^{2}$. Została w ten sposób zagwarantowana nie tylko jedność samej praktyki sądowniczej w Kościele, ale, moim zdaniem, po raz kolejny uwypuklona potrzeba precyzyjnego formułowania przepisów prawnych stanowiących podstawę formowania norm aplikacyjnych.

\footnotetext{
1 Franciszek, Mitis Iudex Dominus Iesus (dalej: MIDI), Kan. 1683, $1^{0} \mathrm{KPK}$. W dalszej części opracowania odwołuję się do systematyki kodeksowej zgodnie z tekstem KPK w motu proprio MIDI.

2 Papieska Rada Ds. Tekstów Prawnych, Prot. N. 15138/ 2015, https://bit.ly/ ius2019-2-1 [dostęp 8.07.2020] oraz Prot. N. 15139/2015, https://bit.ly/ius2019-2-2 [dostęp 29.10.2020].
} 
Temu zagadnieniu chciałbym poświęcić przeprowadzone rozważania w oparciu o odpowiedź Papieskiej Rady. Moją uwagę skoncentruję nie tyle na samym rozwiązaniu, które nie pozostawia interpretacyjnych wątpliwości, co na poszukiwaniu podstaw takiej decyzji i ewentualnie powiązanych z przypadkiem prawnym innych możliwości rozwiązań. Intrygującym dla mnie zagadnieniem jest adekwatność podanego rozwiązania do faktycznych założeń reformy procesu małżeńskiego, a nie w odniesieniu do sytuacji, w których ujawniają się faktyczne trudności związane z możliwością aplikacji przepisu wraz z podanym w odpowiedzi wyjaśnieniem. Wymóg zgody małżonków w wielu sytuacjach, które niesie z sobą życie i losy małżonków po faktycznym rozpadzie małżeństwa, jeśli jest możliwy do osiągnięcia, to jednak może sprawiać wiele problemów związanych z jego uzyskaniem³ ${ }^{3}$ Czy $\mathrm{w}$ takim razie rozwiązania prawne, $\mathrm{z}$ którymi mamy do czynienia, nie ograniczają możliwości prowadzenia procesu przed biskupem z powodu niemożności osiągnięcia zgody małżonków? To zagadnienie stało się punktem odniesienia dla moich przemyśleń w świetle Franciszkowych założeń reformy procesu małżeńskiego.

\section{Odpowiedź na wątpliwość}

Wątpliwość odnosząca się do tekstu kan. 1683, $1^{0}$ dotyczyła zgody drugiego małżonka, o ile prośba o proces przed biskupem została zgłoszona przez drugiego z nich. W szczególe chodziło o sposób, w jaki należy uzyskać ową zgodę. Prośba o wyjaśnienie, z którą zwrócono się do Papieskiej Rady opierała się na możliwości zastosowania analogii do art. $11 \$ 2$ Zasad proceduralnych w sprawie o stwierdzenie nieważności małżeństwa. W artykule tym zostało postanowione, że „strona pozwana nie sprzeciwia się żądaniu, jeżeli zdaje się na sprawiedliwość sądu lub prawidłowo wezwana po raz drugi, nie udziela odpowiedzi”. Problem dotyczył możliwości aplikacji tego

\footnotetext{
3 Na takie wątpliwości praktyczne zwróciła uwagę M. Greszata-Telusiewicz, Processus brevior, w: J. KRAJCZYŃski (red.), Proces małżeński według motu proprio „Mitis Iudex Dominus Iesus”, Płock 2015, s. 84-85.
} 
postanowienia do procesu przed biskupem w sytuacji, w której strona pozwana po raz drugi nie udziela odpowiedzi. Czy zatem można traktować taką decyzję jako wyraz zgody na prowadzenie procesu przed biskupem? Odpowiedź Papieskiej Rady nie pozostawia wątpliwości. Zgoda drugiej strony musi być wyrażona w sposób wyraźny, gwarantujący publicznie i jednoznacznie (nieodwołalnie) jej wolę na prowadzenie procesu przed biskupem. Uzyskana w ten sposób zgoda jest warunkiem sine qua non rozpoczęcia procesu skróconego ${ }^{4}$.

Żądanie wyraźnej zgody na rozpoczęcie takiego procesu jest elementem wskazującym na aktywny aspekt uczestnictwa drugiej strony $\mathrm{w}$ procesie. Jednak wola rozpoczęcia procesu w takim trybie i chęć uczestnictwa w nim nie jest jednoznaczna z możliwością przyjęcia sprawy i jej rozpatrywania zgodnie z wolą stron. Warunkiem rozpoczęcia procesu jest również zgoda co do przedstawionych tytułów nieważności, czyli faktyczne utożsamienie się z przyczynami prowadzącymi do rozpadu związku małżeńskiego i nieodwracalność tej sytuacji, „tak iż nie ma możliwości wznowienia wspólnoty życia małżeńskiego" ". W przypadku zgody na prowadzenie procesu przed biskupem przy jednoczesnym negowaniu tytułów nieważności małżeństwa zawartych w prośbie, czy też sprzeciwianie się żądaniu orzeczenia nieważności nie jest możliwe przyjęcie sprawy w trybie procesu skróconego ${ }^{6}$. W tej sytuacji zgoda formalna na rozpoczęcie procesu stałaby w sprzeczności do założeń szybkości procesowej opartej na pewności faktów, na których prośba się opiera i które „W sposób oczywisty wskazują na nieważność"7 małżeństwa.

4 Prot. N. 15139/2015.

5 Kan. 1675 KPK.

6 P. Skonieczny (red.), Praktyczny komentarz do Listu apostolskiego motu proprio Mitis Iudex Dominus Iesus papieża Franciszka, Tarnów 2015, s. 167.

${ }^{7}$ Kan. $1683,2^{0}$ KPK. 


\section{Racje uzasadniające}

Papieska Rada udzielając odpowiedzi podała jej uzasadnienie. Wskazała, że powołanie się na art. $11 \S 2$ Zasad proceduralnych jest niewłaściwe dla interpretacji postanowienia zawartego w kan. $1683,1^{0}$. Artykuł dotyczy bowiem zwykłego procesu o stwierdzenie nieważności małżeństwa. $W$ dalszej części uzasadnienia mamy do czynienia z wyraźnym stwierdzeniem Rady, że prawodawca ustanawiając normę $\mathrm{w}$ tymże artykule kieruje się domniemaniem, iż „strona pozwana nie sprzeciwia się żądaniu ... [gdy] wezwana po raz drugi nie sprzeciwia się żądaniu".

Uzasadnienie odpowiedzi Rady opiera się na dwóch racjach. Pierwsza z nich dotyczy braku możliwości stosowania w obu przypadkach (proces zwyczajny i proces przed biskupem) wnioskowania per analogiam a simili. U podstaw takiego wnioskowania muszą znajdować się podobne stany faktyczne, których racja istnienia prowadzi do takich samych lub podobnych wniosków. W omawianej sytuacji nie mamy jednak do czynienia z podobnymi przypadkami. Wskazuje na to sama systematyka nowych przepisów traktująca proces zwykły i proces przed biskupem w postaci dwóch równorzędnych jednostek systematycznych tekstu prawnego (artykuły). Podobieństw nie można się doszukiwać odwołując się do różnych form procesu dotyczących stwierdzenia nieważności małżeństwa jako kategorii ogólnej z dwoma specyficznymi i równoległymi procedurami. Podobnie należałoby zatem traktować proces oparty na dokumentach.

Pomiędzy procesem zwyczajnym a procesem przed biskupem nie realizuje się podobieństwo stanów prawnych, lecz jedynie cel, któremu oba procesy służą. Proces przed biskupem należy traktować jako wyjątek od procesu zwykłego ze względu na racje pozwalające na przeprowadzenie go w przypadku oczywistych i niepowątpiewalnych okoliczności, które dopuszczają, a wręcz wskazują na odejście od procesu zwyczajnego. Elementem przemawiającym za szczególnością procesu przed biskupem jest zbiór okoliczności zawężających zakres przedmiotowy hipotezy normy prawnej. Szczegółowość decyduje o niemożliwości zastosowania wnioskowania per analogiam, gdyż 
racje normy ogólnej niekoniecznie muszą się weryfikować w normie szczegółowej. W tej sytuacji można odwołać się do reguły kolizyjnej lex specialis derogat legi generali.

Dodatkowym argumentem przemawiającym za słusznością odpowiedzi udzielonej przez Radę jest stwierdzenie, że - w przypadku procesu zwykłego uznaje się stronę po raz drugi wezwaną zgodnie z prawem za niesprzeciwiającą się żądaniu - mamy do czynienia $\mathrm{z}$ domniemaniem. Domniemanie, o ile nie ma charakteru iuris ac de iure, ustaje w momencie przeprowadzenia przeciwdowodzenia. Brak wyrażenia sprzeciwu nie oznacza pewności udzielenia zgody. Stronę działającą w ten sposób jedynie „uważa się" ${ }^{9}$ za tę, która nie sprzeciwia się żądaniu. Pewność wyrażonej zgody jest bowiem elementem przemawiającym za pewnością okoliczności, które faktycznie doprowadziły do nieodwracalnego rozpadu związku małżeńskiego. To odróżnia dwa sposoby prowadzenia procesu o stwierdzenie nieważności małżeństwa: zwykły i przed biskupem. Z sytuacją pewności nie mamy do czynienia w przypadku podwójnego braku odpowiedzi ze strony pozwanej. Domniemanie wyrażone w art. $11 \S 2$ ma charakter domniemania jedynie iuris tantum. Przemawiają za tym inne przepisy dotyczące procesu małżeńskiego zawarte w Instrukcji Dignitas connubii. Domniemanie może zostać bowiem obalone, gdy strona udowodni, że brak jej odpowiedzi został spowodowany przez zgodną z prawem przeszkodę ${ }^{10}$. Przepisy Instrukcji dopuszczają również możliwość włączenia się, do momentu rozstrzygnięcia procesu, drugiej strony uznanej za nieobecną o ile sama stawi się w sądzie lub nadeśle swoje odpowiedzi, przedstawi wnioski i dowody. Nabywa w ten sposób prawo uczestnictwa w procesie ze wszystkimi przysługującymi stronie prawami ${ }^{11}$.

8 T. GaŁkowski, Papieska Rada ds. Tekstów Prawnych wobec wątpliwości zwiazanych z Listem apostolskim "Mitis Iudex Dominus Iesus”, „Ius Mtrimoniale” 27 (2016) 2, s. 41.

9 Art. $11 \$ 2$.

10 Dignitas connubii (dalej: DC), art. $139 \$ 2$.

11 DC, art. $139 \$ 1$. 
W sytuacji procesu przed biskupem warunkiem jego rozpoczęcia są sytuacje (okoliczności), co do których można osiągnąć odpowiedni stan pewności w chwili analizy skargi powodowej. Jednym z elementów przeważających za osiągnięciem takiego stanu pewności jest zgoda na prowadzenie procesu przez drugą stronę wyrażoną w sposób wyraźny. Prawodawca nie dopuszcza w tym momencie domniemania, gdyż możliwość jego obalenia przez dowód przeciwny niweczyłaby cel samego procesu i z góry zakładałaby konieczność odesłania sprawy do rozpatrzenia na drodze procesu zwykłego. Z takiej sytuacji można wyciągnąć równocześnie wnioski dotyczące samego prawa i umiejętności prawodawczych. Prawo mogłoby utracić swoją wartość, gdyby uprzednio dopuszczano ewentualne sytuacje eliminujące pewność sytuacji prawnych, na których opiera się proces przed biskupem.

Warto, moim zdaniem, zwrócić uwagę na jeszcze jedną rację przemawiającą za słusznością odpowiedzi Papieskiej Rady dotyczącą analizowanej sytuacji prawnej. W przypadku procesu zwykłego, którego dotyczy art. $11 \$ 2$ Zasad proceduralnych prawodawca w odniesieniu do drugiej strony procesu stosuje określenie „strona pozwana” wyraźnie wskazując, na dwie różne strony procesowego sporu. W przypadku procesu przed biskupem nie istnieje rozróżnienie na stronę powodową i pozwaną. Obie strony możemy traktować na zasadzie czynnego współuczestnictwa, gdyż występują wspólnie z prośbą o stwierdzenie nieważności małżeństwa w trybie procesu przed biskupem. Rolę strony pozwanej w procesie kontradyktoryjnym pełni

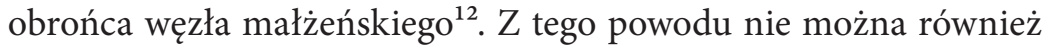
aplikować postanowienia art. $11 \$ 2$ Zasad proceduralnych.

\section{Ranga odpowiedzi Papieskiej Rady ds. Tekstów Prawnych}

Wspomniane powyżej trudności związane z uzyskaniem zgody drugiej strony na prowadzenie procesu przed biskupem, pomimo istniejącej odpowiedzi Papieskiej Rady ds. Tekstów Prawnych, mogą

\footnotetext{
12 P.V. Pinto, Małżeństwo i rodzina na synodalnej ścieżce papieża Franciszka, Città di Castello PG 2019, s. 196.
} 
wzbudzać dywagacje dotyczące rzeczywistych możliwości wyjścia naprzeciw papieskim pragnieniom rozwiązania sytuacji osób, których małżeństwo się rozpadło wobec rzeczywistych przesłanek potwierdzających jego nieważność. Takimi przesłankami mogłyby być chociażby zaświadczenia lekarskie potwierdzające choroby psychiczne będące przyczyną niezdolności natury psychicznej do podjęcia istotnych obowiązków małżeńskich, których brak podjęcia możliwy jest do poświadczenia przez ewentualnych świadków, czy też inne dokumenty wskazujące na możliwość zaistnienia okoliczności dopuszczających „rozpoznanie sprawy o nieważność małżeństwa, stosując proces skrócony" ${ }^{13}$. Na podstawie tych dokumentów można zweryfikować „okoliczności dotyczące faktów i osób [...], które nie wymagają przeprowadzenia dokładniejszego badania albo dochodzenia oraz w sposób oczywisty wskazują na nieważność"14. W świecie rozwoju informatycznych form komunikacji takie dokumenty coraz częściej pojawiają się w kościelnych trybunałach rozpatrujących sprawy o nieważność małżeństwa ${ }^{15}$. Brak uzyskania zgody na podstawie obowiązujących przepisów prawnych uniemożliwia w takiej sytuacji przeprowadzenie procesu przed biskupem. Nie można również zastosować ustnego procesu spornego ${ }^{16}$, który w takich sytuacjach mógłby wyjść naprzeciw pragnieniom szybszego uregulowania sytuacji prawnej małżonków po rozpadzie ich małżeństwa ${ }^{17}$. Wobec takiej sytuacji narzuca się nieuchronnie pytanie, czy zatem sposób uzyskania zgody drugiej strony tak, jak przedstawiła to w swojej

\footnotetext{
13 Zasady proceduralne, art. $14 \$ 1$.

14 Kan. 1683, $2^{0}$ KPK.

15 T. Rozkrut, Dowód z nowych technologii komunikacji we współczesnym procesie małżeńskim, w: T. Rozkrut (red.), Reforma procesowa papieża Franciszka-pierwsze doświadczenie. Materiały z ogólnopolskiego spotkania pracowników sądownictwa kościelnego w Gródku nad Dunajcem w dniach 12-13 czerwca 2017 roku, Tarnów 2018, s. 143-161.

16 Kan. 1690 KPK.

17 T. GaŁkowski, Uwagi wokół „Instrumentum laboris” XIV Generalnego Zebrania Zwyczajnego Synodu Biskupów dotyczace procesu małżeńskiego, „Roczniki Nauk Prawnych" 15 (2015) nr 3, s. 115-128.
} 
odpowiedzi Papieska Rada ds. Tekstów Prawnych, nie niweluje założeń procesu przed biskupem?

Uzasadnione wydaje się w tym momencie stwierdzenie, że odpowiedź Papieskiej Rady nie zamyka jednak drogi dalszym możliwym nie tylko regulacjom ustawodawczym, gdyż sama Rada takich uprawnień nie posiada, chyba że w formie interpretacji autentycznych per modum legis, co dalszym dywagacjom interpretacyjnym kan. 1683, $1^{0}$. Odpowiedź Rady nie jest bowiem ostateczna, lecz została sprowokowana skierowanym do niej pytaniem zawierającym wątpliwość.

$\mathrm{Na}$ swojej stronie internetowej Rada tłumaczy charakter wypowiedzi stwierdzając, że odpowiedzi szczegółowe dotyczą kwestii szczegółowych, które znajdują się w interesie ogółu tych, którzy są odpowiedzialni w Kościele za prawidłową aplikację prawa. Nie posiadają one formalnej wartości odpowiedzi autentycznych w sensie wyrażonym w kan. $16 \$ 1$. Są wynikiem dogłębnego studium argumentu przedstawionego Radzie i wskazują jej stanowisko w konkretnych zagadnieniach w sensie przewidzianym w kan. $19 \mathrm{KPK}^{18}$. Odpowiedzi na szczegółowe zapytania kierowane do Papieskiej Rady posiadają zatem charakter raczej porad dotyczących właściwej aplikacji prawa niż opinii czy ekspertyz.

W odniesieniu do omawianej odpowiedzi pojawiają się jednak znaki zapytania dotyczące jej charakteru w sensie wyrażonym w kan. 19. I to z dwóch powodów. Po pierwsze kan. 19 odnosi się do konieczności podjęcia decyzji w sytuacji prawnej, gdy brak jest „wyraźnej ustawy, powszechnej lub partykularnej, albo prawa zwyczajowego”. Taka sytuacja nie weryfikuje się w przypadku kan. $1683,1^{0}$, ponieważ istnieje odpowiedni przepis, którego interpretacja dokonana w kontekście innych przepisów ustawy prowadzi do wniosków zawartych w odpowiedzi Rady. Sama Rada formułując odpowiedź opiera się na istniejących przepisach. Po drugie w sytuacji przewidzianej w kan.

18 Szerzej na temat analizy poszczególnych wypowiedzi i odpowiedzi Papieskiej Rady ds. Tekstów prawnych pisałem w artykule Papieska Rada ds. Tekstów Prawnych wobec wątpliwości związanych z Listem apostolskim "Mitis Iudex Dominus Iesus”, s. 24-39. 
19 elementami umożliwiającymi podjęcie decyzji w sytuacji prawnej bez istnienia odpowiedniej ustawy czy zwyczaju mogą być: jurysprudencja, praktyka Kurii Rzymskiej oraz powszechna i stała opinia uczonych. Nie sądzę, że któryś z tych elementów posiada odniesienie do treści odpowiedzi Rady, która została wydana jeszcze przed wejściem w życie Listu apostolskiego Mitis Iudex Dominus Iesus. Trudno w odniesieniu do tak nowej sytuacji jaką jest proces przed biskupem mówić o praktyce Kurii Rzymskiej, czy utrwalonej jurysprudencji. Ewentualnie aplikację mógłby znaleźć trzeci element, a mianowicie powszechna i stała opinia uczonych. Można zgodzić się co do opinii uczonych zasiadających w Radzie, ale nie można jej zweryfikować w kategoriach stałości (wytrzymująca próbę czasu) i powszechności (podzielana przez innych) ${ }^{19}$.

\section{Inne możliwości spojrzenia na kwestię uzyskania zgody}

Nie uważam, że trzeba odwoływać się w tym momencie do kan. 19, skoro można dać odpowiedź w oparciu o istniejące przepisy. Ale skoro Rada mówi o własnych odpowiedziach w sensie kan. 19 to może warto spojrzeć na to w świetle innych możliwości, które kanon proponuje. Poniższe rozważania są próbą rozszerzenia możliwości interpretacyjnych, co nie oznacza, że mają na celu deprecjonowanie odpowiedzi udzielonej przez Papieską Radę. Należy mieć na uwadze, że rozwiązania proponowane w kan. 19 dotyczą poszczególnych i jednostkowych przypadków prawnych, a odpowiedź Rady wyjaśnia istniejącą normę obejmującą takie same i powtarzalne sytuacje.

Oprócz trzech wyżej wymienionych środków rozwiązania przypadków prawnych w kan. 19 zostały wskazane ogólne zasady prawa z zachowaniem słuszności kanonicznej. Słuszność pełni tu rolę korygującą zastosowanie samych zasad umożliwiając dotarcie do istoty prawa i zawartych w nim przepisów ${ }^{20}$.

19 T. GaŁkowski, Zasady prawa w prawie kanonicznym, Warszawa 2020, s. 65.

20 Tamże, s. 106-115. 
W odniesieniu do pytania przedstawionego Radzie pojawiały się argumenty odwołujące się do zasady prawa zawartej w Liber sextus Bonifacego VIII, która brzmi następująco: Qui tacet, consentire videtur ${ }^{21}$. Stanowisko dotyczące możliwości aplikacji zasady opierało się na domniemaniu zgody strony, która nie dołączyła się do prośby drugiej strony składającej skargę powodową do trybunału kościelnego, o ile, zgodnie $\mathrm{z}$ prawem powiadomiona, nie odpowiedziała na zapytanie sądowe ${ }^{22}$. Takie rozumowanie znalazło się u podstaw zapytania skierowanego do Rady. Nie można jednak wykluczyć, że wzbudzało niepewność co do zastosowania samej zasady, skoro zapytanie zostało przedstawione. Odpowiedź Rady nie zawiera odniesienia do tej zasady, nie wyjaśnia braku podstaw do jej zastosowania, gdyż zwyczajnie odpowiada ona na pytania odwołując się do istniejących przepisów prawnych. Wyjaśnienia wraz z poszukiwaniem ich racji przynależą do nauki wyrażonej stałą i powszechną opinią uczonych.

Zasada wyrażona w R.I. 43 nie jest zasadą absolutną. W opozycji do niej znajduje się następna zasada, która mówi Is, qui tacet, non fatetur, sed non utique negare videtur ${ }^{23}$, co można wyrazić stwierdzeniem quis tacet, nihil dicit ${ }^{24}$. W odniesieniu do tych dwóch zasad, które, zdawać by się mogło, można by aplikować do omawianej sytuacji, nieocenioną rolę odgrywa słuszność kanoniczna korygująca ich zastosowanie i pozwalająca dotrzeć do istoty prawa przede wszystkim w zamyśle samego prawodawcy.

Poszczególne zasady zostały wypracowane w oparciu o konkretne i powtarzające się podobne przypadki prawne. $Z$ tego względu nie tyle znajomość samych zasad, lecz przede wszystkim znajomość racji znajdujących się u podstaw ich istnienia pozwala racjonalnie i ze słusznością ocenić ich przydatność do konkretnych sytuacji.

\footnotetext{
21 R. I. 43: Kto milczy, wydaje się zgadzać. Cyt. za A. DęBı́́ski, Kościół i prawo rzymskie, Lublin 2008, s. 168.

22 P.V. Pinto, Małżeństwo i rodzina na synodalnej ścieżce papieża Franciszka, Città di Castello PG 2019, s. 197.

23 R. I. 44: Ten, kto milczy, nie potwierdza, ale nie wydaje się również, że zaprzecza.

24 Kto milczy, nic nie mówi.
} 
Zasada qui tacet, consentire videtur odnosi się do sytuacji, w której osoba pytana mogłaby odpowiedzieć negatywnie, ale tego nie czyni. Drugą zasadę is, qui tacet, non fatetur, sed non utique negare videtur można aplikować tylko w sytuacjach, w których podmiot nie jest zobligowany do odpowiedzi ${ }^{25}$. Zestawienie obu zasad w rozważanym przypadku wymagania zgody drugiej strony na rozpoczęcie procesu przed biskupem wskazuje, że posiadają podstawę ich aplikacji. Osoba wzywana do sądu może nie odpowiedzieć na wezwanie. Obowiązek troski o stawiennictwo stron w procesie małżeńskim spoczywa na przewodniczącym kolegium sędziowskiego oraz na ponensie ${ }^{26}$. Brak jednak odpowiedzi z jej strony można odczytać w podwójnym znaczeniu: ani nie potwierdza, ani nie zaprzecza. Strona procesowa po prostu nic nie stwierdza, skoro milczy. Trudno w takiej sytuacji dojść do przekonania, że osoba wyraziła zgodę na rozpoczęcie procesu przed biskupem. Taka zgoda jest jednak wymagana jako warunek sine qua non rozpoczęcia procesu.

W odniesieniu do pierwszej zasady można by uznać ją za słuszną przy domniemaniu zgody. Osoba mogła bowiem odpowiedzieć negatywnie, mogła nie zgodzić się na prowadzenie procesu, ale nie odpowiedziała, co sugeruje, że zgodziła się na proces. Jednak w przypadku tej zasady mamy do czynienia z domniemaniem, na co wyraźnie wskazuje użyta forma videtur (zdaje się). Niemożność aplikacji tej zasady wynika również ze stwierdzenia Rady dotyczącego pewności wyrażonej zgody.

Na gruncie odpowiedzi i dwóch zasad prawa może jednak zrodzić się pytanie o ostateczność rozwiązania podanego przez Papieską Radę. Sama natura formalnej odpowiedzi, którą posłużyła się Rada, nie wskazuje na taką ostateczność, co nie podważa jednak jej obowiązywalności. Moim zdaniem, kwestia, jeśli nie otwarta, to jednak pozostaje nie do końca zamknięta w odniesieniu do dalszych możliwości określenia sposobów uzyskiwania zgody. Przyczyną takiego stanu

${ }^{25}$ E. Baura, Parte generale del diritto canonico. Diritto e sistema normativo, Roma 2012, s. 218.

${ }^{26} D C$, art. $138 \S 2$. 
rzeczy są problemy dotyczące możliwości uzyskania zgody w niektórych przypadkach, które weryfikują się w życiu małżonków ${ }^{27}$. Czy zatem w takich sytuacjach możliwość odwołania się do zasad prawa nie mogłaby stać się racją procedowania przed biskupem? Chodzi bowiem o prawo, a nie tylko o konkretne rozwiązania normatywne, chodzi o sytuację prawną stron, które rzeczywiście rozpoznają nieważność swojego małżeństwa i co do której sytuacji coraz bardziej się przekonują w procesie duszpasterskiego towarzyszenia stronom przez ich duszpasterza, o czym wyraźnie pisał papież Franciszek w adhortacji Amoris laetitia ${ }^{28}$ Odpowiedź stwierdzająca, że istnieje możliwość rozpoznania sytuacji małżonków i ważności małżeństwa na drodze procesu zwykłego jest poprawna. Nie zawsze jednak może weryfikować się wobec ograniczeń czasowych i trudnych sytuacji, np. w sytuacji ciężkiej choroby jednej ze stron, czy zbliżającego się kresu życia.

Podobny do opisywanej sytuacji może być przypadek prowadzenia procesu zwykłego bez uczestnictwa jednej strony. Czy w tej sytuacji przedłużony czas na zbieranie dowodów i instrukcję sprawy, przy jego ograniczeniu w przypadku procesu przed biskupem, ale przy pewności dowodowej, nie prowadzi do podobnych decyzji sądowych? Czy brak wyraźnej zgody w sytuacji niemożliwości jej wyrażenia wobec oczywistych dowodów przemawiających za nieważnością małżeństwa nie jest formą legalistycznego podejścia do sytuacji prawnej osób wierzących w Kościele? Takich pytań można postawić więcej. Odpowiedzi na nie można poszukiwać w Franciszkowych ideach przyświecających nie tylko samej reformie procesu małżeńskiego, ale w świetle jego szerszego spojrzenia na małżeństwo i rodzinę oraz w świetle wskazań dotyczących duszpasterskiego towarzyszenia i rozpoznania sytuacji wyrażonych w Amoris laetitia. Papież Franciszek pozostaje wierny tym wskazaniom, nadając im rangę normatywną w ramach Zasad proceduralnych w sprawach o stwierdzenie

27 Por. przypis 3.

28 FranciszeK, Amoris laetitia, rozdział VIII. 
nieważności małżeństwa ${ }^{29}$ oraz wskazując na okoliczności rzeczy lub osób dopuszczające rozpoznanie sprawy przed biskupem ${ }^{30}$. Uważam, że przyczyny wskazujące na nieważność związku małżeńskiego, o ile spełniają kryteria rozumnego prawdopodobieństwa powinny mieć, o ile nie przewagę nad formalną stroną wyraźnego wyrażenia zgody na proces przed biskupem, to jednak powinny być brane pod uwage przy możliwości oceny takiej możliwości.

\section{Zakończenie}

Odpowiedź Papieskiej Rady ds. Tekstów Prawnych reguluje jedność praktyki sądowej i właściwej aplikacji przepisów prawnych. Jest odpowiedzią pewną, ale nie do końca zgodziłbym się określić ją jako ostateczną w znaczeniu, że całkowicie eliminuje możliwości szerszego dostrzeżenia sytuacji prawnej małżonków po nieodwołalnym rozpadzie ich małżeństwa. Nie wydaje mi się również, by pokusa normatywizmu prawnego popartego formalizmem posiadała wartość nadrzędną w stosunku do jurydycznej sytuacji prawnej i przemawiających za nią stanów faktycznych. Takie właśnie stany są podstawą procesów o stwierdzenie nieważności małżeństwa. Poszukiwanie racji istniejących rozwiązań prawnych poszerza i rozwija umiejętności przyglądania się sytuacjom prawnym w pełnym ich aspekcie i przyczynia się dokładnego ich opisywania, tak by w ich świetle poszukiwać adekwatnych dla nich norm wskazujących na sytuację prawną osób w Kościele.

\section{Consent of the Spouse in the Briefer Matrimonial Process before the Bishop}

\section{Summary}

The study analyzes the answer of the Pontifical Council for Legislative Texts regarding the need to obtain the explicit consent of the other party as

\footnotetext{
29 Art. 2-5.

30 Art. $14 \$ 1$.
} 
a sine qua non condition for the commencement of the Briefer Matrimonial Process before the Bishop. The author analyzes the rations for formulating the content of the answer, but also points to situations that impede obtaining such a consent. He points out that the actual grounds for the annulment of a marriage should prevail over the formal reason.

Słowa kluczowe: skrócony proces małżeński przed biskupem, rozpoczęcie, zgoda stron.

Key-words: briefer matrimonial process, commencement, consent of the spouses.

\section{Nota o autorze:}

O. Tomasz Gałkowski CP - kapłan z zakonu pasjonistów, doktor habilitowany nauk prawnych w zakresie prawa kanonicznego, profesor nadzwyczajny Uniwersytetu Kardynała Stefana Wyszyńskiego w Warszawie, sędzia Trybunału Metropolitalnego w Łodzi. 